and the future form and direction of Australian union training, remains clouded. This situation results from the Liberal and Country Party (LCP) Coalition Government's August 1978 controversial amendments to the Trade Union Training Act, amendments that dramatically altered TUTA's organisational structure and executive control. Details of the events leading to the legislative change and the specific changes have been documented elsewhere. ${ }^{31}$ Suffice to say that the LCP retained TUTA as an independent and public funded training institution but removed union control of the Authority's Executive body. Union reaction to the amendments was predictably hostile but stopped short of either industrial action or boycotting TUTA courses. Some unions, however, have suggested that the 'emasculation' will undermine union confidence in the Authority.

If TUTA remains Australia's major provider of union training (and clearly the Authority's position is strengthened by the dearth of alternative training facilities) the fruits of its labour and the nature of its role in the implementation of union policy should become more evident in the 1980's. The impact of training on union administration, the job performance of union personnel (including the preparation and presentation of union cases and research) and employeremployee relations generally, are three benchmarks worthy of future surveillance.

31. Cupper, ibid.

\title{
EDUCATION WITHIN THE TRADE UNION MOVEMENT - SOME SUGGESTIONS FOR DEVELOPMENT
}

- Michael Hanne*

\section{Six kinds of trade union education}

The term "trade union education" can be used to cover quite a number of different activities. I think it makes sense to see all these activities in terms of a spectrum that ranges from the very specific training of people for a particular role within the trade union movement, through the broader area of education about the trade unions, to trade-union-based worker education in the broadest sense. Six main activities can probably be usefully distinguished within this whole spectrum:

1. the training of job-delegates, branch officers and full-time union officials in the (increasingly) complex skills they need to work effectively on behalf of their members;

2. the education of rank-and-file members about the importance and value of the union movement, its history, objectives, the main issues it faces, and about how to get the maximum benefit from belonging to a trade union;

3. the education of the public at large in the functions and importance of trade unions with the particular aim of counteracting the generally unsympathetic image of trade unions presented by newspapers and television;

- Michael Hanne is Senior Lecturer in Italian in the Department of Romance Languages at the University of Auckland 
4. the education of members (and others) in questions of ideology, political philosophy, about the need for radical economic and social change and the various means by which it can be achieved;

5. the organising of remedial education for members and their families whose formal education has in one way or another been lacking and of re-training for members who need to acquire new skills;

6 the provision of facilities for members to develop cultural and leisure interests in rewarding ways.

(This classification of types of trade union education is largely taken from a talk given in New Zealand in 1967 by the American trade union educationist, Joesph Mire. It was published under the title "Trade Union Education" in a booklet called Trade Union Education: Some Pointers for New Zealand, edited by E. J. Keating (Victoria University of Wellington, 1969).

\section{Education must be a central activity of a trade union movement.}

When you look at trade union education in these terms, it becomes obvious that education can't be regarded as just an "optional extra", a frill around the edges of a trade union movement. Trade union education is a bundle of essential processes which are central to the proper working of any trade union. In the simplest terms: without skilled officials, without informed and aware members and without a wide public which is at least beginning to understand the function of trade unions, the trade union movement cannot possibly be an effective force.

I don't think many union officials in New Zealand would disagree with much of what l've said so far. Some would perhaps prefer not to use the label "education" for all these activities because they see some of them at least as just part of the everyday business of running a trade union: learning to do their own jobs, looking after the welfare of their members, keeping their members informed, and so on. In my view, that doesn't at all stop such activities being education. We must fight the tendency to think of education as something separate and special, which only happens in class-rooms. It should be something that everyone experiences every day in living, learning, changing as a person.

Other unionists would argue that the responsibility for remedial education, for re-training, and for workers generally to extend their education through their adult lives, lies with the state. But the state has, to a large extent, failed in that responsibility and the trade union movement, as the major force representing working people, needs to concern itself directly with putting that failure right. Moreover an education movement initiated by working people, based in their experiences, interests and needs, has a value for them which goes far beyond that offered by the state education system.

Other unionists again would say that, though it might be desirable for trade unions to be active in all these fields, they simply don't at the moment have either the money or the staff to give high priority to education. Here I come back to the point that education, in the various senses I listed at the beginning, is both central and essential to a healthy trade union movement.

\section{The trade unions' dilemma over education resources}

Whenever the trade union movement attempts to widen and deepen its education programme, it is faced with a crucial basic dilemma. Its own resources for education, in terms of finance, equipment, libraries, rooms and 
staff are very limited. Moreover the trade unions have gained far less access to the vast resources possessed by the universities and technical institutes than, for instance, the managerial and professional groups have. It is extraordinary, scandalous in fact, that in the Auckland area, the Centre for Continuing Education at Auckland University and the Auckland, Carrington and Manukau Technical Institutes do not run a single course in trade union studies between them - whereas they offer a wide variety of courses for managers, personnel officers and industrial supervisors. Similarly the consultancy services offered by researchers in the technical institutes and universities to trade unions are minimal compared with those offered to management.

It would seem obvious then that the trade unions should be pressing for their fair share of access to the resources of the technical institutes and universities. To a certain extent this has already begun to happen - but less than might be expected. There are several clear reasons for this.

Trade unionists are very suspicious of the state educational institutions and generally, I believe, with justification. They see the universities, in particular, as allied almost exclusively to professional and managerial interests, as the training ground for the doctors, the lawyers, the accountants, the engineers, the industrial managers and so on. (And it is significant that the governing bodies of universities, the University Councils, are made up almost exclusively of such people. Is there a single trade unionist on any University Council in New Zealand?) In fact trade unionists are acutely aware of the universities' role as a mechanism for helping to maintain the dominance in society of certain restricted groups, rather than as agents of socal change. (Christopher Wainwright's book The Degree Merchants: Inside the New Zealand University System (Auckland, 1977) argues this point with plenty of evidence.)

The trade unions, have, largely for these reasons, been quite reluctant until recently to take university-trained specialists on to their staff leconomists, industrial relations specialists, management specialitis, sociologists, educationists, and so on) even though some of their skills have been badly needed in the trade union movement. They have also found that universities tend to want, in exchange for access to their resources, exclusive control over the content of courses offered on university premises, despite the fact that the unionists are generally - and I'm thinking particularly of training courses for union officials - in a much better position to know what their specific wants and needs are.

Even so, I shall argue in this paper that the trade unions should increase their pressure on the education institutions to give them much greater useful access to their resources for the purpose of trade union education. And I shall argue that people in the universities and technical institutes need to give much more thought than they have done previously to the question of how they can most usefully open up to the trade union movement the resources which they control.

\section{Some trade union education schemes in Britain (and one in Italy)}

In the second part of this paper I shall report on some of the many trade union education schemes I saw at work in Britain during a period of study leave in 1978. I want to illustrate not just the extraordinary diversity of possible educational schemes, but more specifically the variety of ways in which the trade union movement can join forces with educational (and other) institutions to serve the interests of working people. 


\section{An extraordinary example of co-operation between trade unions and academics in South Wales}

I want to start with the one project which impressed me more than all the others - in fact more than any other educational experience I've ever had - and I've been continuously involved with educational institutions ever since I started primary school thirty years ago! This was a weekend school on The Making of the Welsh Working Class held in Swansea in South Wales. The most remarkable thing about the school was who organised it and took part in it.

It was organised jointly by the Wales T.U.C., the Society for the Study of Welsh Labour History (Llafur), and the Extra-Mural Studies Department of University College, Swansea. (It was held at University College.) The conference was attended by three groups of roughly equal size: firstly, full-time union officials, shop stewards, rank-and-file unionists; secondly, academic historians, political scientists, sociologists; and thirdly, individuals from the Labour Party, Communist Party, schools, libraries, local history societies etc.

Now the history of the industrial working class in South Wales is longer than that of almost any other country, because South Wales, with its vast deposits of coal and iron ore was, back in the 1750 s and before, one of the points from which the industrial revolution began. And over the period up to the First World War, millions of men, women and children migrated from other parts of Wales, England, Scotland, Ireland, even Spain and Italy, to work and to live the dangerous, unhealthy, exploited lives of miners and iron-workers. Although this century has seen the steady improvement of working conditions and wages, especially for miners, there has also taken place a dramatic and disastrous running-down of coal mining in the area, so that the work-force of 280,000 in the mines early this century has been reduced to 28,000 today. This, in turn, has led to a very high level of unemployment, large-scale emigration and the breaking-up of the strong communities which the mining villages used to be.

The different groups of participants at the weekend school-and there were about 400 people there-obviously had quite different contributions to make, but which blended together marvellously. The academic historians gave papers on labour struggles up to the First World War, on living conditions, disease, mortality rates, on the beginnings of organisation and self-education by the workers, repressive measures by the employers assisted by the police and army, the emergence of an effective trade union movement and the struggle for improved pay, working conditions and living conditions. Because they made extensive use of unofficial records of events-workers' diaries and memoirs - as well as official records they were able to reconstruct amazingly vivid, detailed pictures of the existence of the early generations of miners.

When we reached the period from 1914 on, there were many veterans present who had been conscientious objectors in the First World War, local leaders in the 1926 General Strike, union or political organisers in the Depression period, volunteers who fought Fascism in the Spanish Civil War, and so on. So they held the floor to recount their memories, to explain and interpret the events they were personally involved in. (The walls of the various rooms in which the school was held were throughout lined with the beautiful, handembroidered banners of each of the miners' union lodges which have survived from the early part of the century.)

The veterans' contributions were followed by speeches from the people who currently represent workers in South Wales in the trade unions and political par- 
ties, in which they analysed the depressed situation of industry in the region today and argued about the direction which the trade union movement should take in the next few years.

The value of such a collaborative experience must be pretty obvious. It brought together people with very different experience and expertise-but all clearly committed to the advancement of working people-to pool their knowledge. Each group valued warmly the contributions of the other groups and came to see their own concerns with new perspectives. Most striking was the recognition amongst everyone of the essential continuity of the struggles of the working class in the region, in changing conditions, over more than 200 years. This naturally gives historical depth and perspective to consideration of the problems facing workers now. The possible range and purpose of committed labour studies became clear to many people for the first time. The historians were reminded of the need to communicate vividly and directly to an audience of non-historians. The unionists came to see the acute relevance of the work the historians were doing for their own concerns. And the historians, in turn, were able to record the veterans' memories of events that happened up to 60 years ago, many of which had not previously been recorded. This, for me, was education coming to life.

That weekend school was not an isolated coming together of trade union and academic forces in South Wales. It was the third annual conference of its type and anyway the Society for the Study of Welsh Labour History is a permanent organisation through which much pooling of experience and skills is going on all the time. The majority of the academics in the Society are of working-class origin and stay close to those origins. Moreover, as anyone who knows South Wales will tell you, the miners particularly have long recognised the vital importance of education to working people, seeing knowledge as a key to the exercise of greater control over the forces that shape their lives. From about 1890 , Miners' Institutes were set up with excellent libraries by the miners of every village in the mining valleys, which specialised in books on politics, economics, sociology and so on, through which many miners educated themselves and each other to a very high level. (With the running down of mining in the region, these libraries are now sadly reduced to the single South Wales Miners' Library, attached to University College, Swansea.) The miners established scholarships to send their children to university, at a time when they could get no other assistance for higher education and they contributed substantially to the setting up of university and labour colleges in South Wales.

Of course South Wales is an unique region. The concentration of such large numbers of people, so scandalously exploited, over such a long period of time, associated with just two gigantic industries, within a country (Wales) which had been oppressed for even longer, brought about a strength of community and consciousness of class interests which one could hardly expect to find anywhere else. The preoccupation with self-education amongst workingpeople in South Wales has doubtless been both a cause and an effect of their strong class-consciousness. But with the depopulation of the mining valleys over the last 30 years and the diversification of industries in the region has come an erosion of the unity and sense of purpose of the working people - and an erosion too of the traditional commitment to worker and trade union education. So, in a sense, the weekend school which so delighted me was no more than the tail-end of a tradition which was once even more vigorous.

I've described that weekend school in South Wales in detail not only because it was a unique and impressive experience for me, but because it was the one 
educational project of all those which I saw in different parts of Britain which cut across more or less all the possible types of trade union education. It contributed directly to the work of trade union officials and in a broader sense to the education of rank-and-file unionists and of non-unionists; it had clear ideological content; and it inspired everyone present, I think, to pursue their studies in the field much further.

\section{In-house training of officials by single unions in Britain}

What I want to do now is look in a much more systematic way at the whole spectrum of other projects I saw at work in Britain (and one in Italy), each of which operated in a much narrower and more specific field than that remarkable Welsh project.

The most specific trade union training is naturally done in Britain, as elsewhere, by the individual union and the sheer size of the larger unions (the Transport and General Workers' Union, for instance, has over 2 million members!) makes it possible for them to devote enormous resources to education. The larger unions have a big education department each and educational staff for every region as well. (Some unions actually have full-time residential colleges of their own for training purposes e.g. T and GWU, the National Union of Railwaymen, the General and Municipal Workers etc.) Training courses available range from induction courses for newly elected shop stewards and health and safety representatives, to in-plant courses tailor-made to the requirements of a specific workforce, to specialised courses for experienced shop-stewards on the law at work, industrial democracy, plant-level bargaining etc, to basic training for branch officers and specialist and advanced courses for experienced branch and district officers.

Most unions recognise that training, at, for instance, shop-steward level, must be continuous and developing. Here for instance is the scheme suggested by the National Association of Local Government Officers for the training of its stewards:

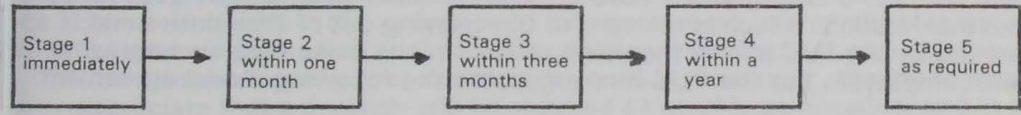

Written job guidance with other self-teaching material and reference documents.
Initial briefing on steward's job with reference to branch rules organisation, policies and collective agreements

\section{Induction}

training continues.
Other

basic

steward training.
Advanced specialist/ refresher courses.
Stages 1 and 2 should be given by each branch individually.
Stages 3,4 and 5 will normally be provided on a district or regional basis.

Public funds are available for Stages 1-3 and basic training in employment law within Stage 4. ${ }^{*}$ 


\section{TUC training courses}

The Trades Union Congress (TUC) offers courses throughout Britain which perform much the same functions as the courses run by the individual big unions. They tend to be used by officials of the smaller unions which don't have a sufficiently large education staff to mount all their own courses - also on subjects which cut across the interests of several unions. The very fact that they are taken by members of such a variety of unions means that they are usually fairly broad in their content.

The basic shop stewards' course consists of a ten-week, one-day-per-week, day release scheme, which, though it was designed by the TUC Education Department, is taught in each district by university continuing education departments, polytechnics, WEAs. ${ }^{*}$ This course is followed, a year or so later, by another ten-day course, a more advanced and/or specialist TUC course covering such areas as: law and the workplace, bargaining information, work study, job evaluation etc.

Two important points need to be made about these courses. Firstly, the TUC nominates the institutions which may teach the courses, and has several times withdrawn courses from institutions whose staff did not teach the courses in the way the TUC thought they should. Secondly, the finance for these courses comes from the Government in two ways: the trainers are paid directly by the Department of Education and Science (not in the normal salary-allocation to the university, polytechnic etc within which the person is employed), and the TUC receives a grant of several million dollars per year for its part in organising them.

The TUC also mounts one-week residential training courses (it, too, has its own training college) for stewards and full-time officials on specific topics such as industrial democracy, the economy etc.

\section{Paid release for training}

Employers in Britain are required in general terms by the Employment Protection Act 1975 to grant paid leave to union officials for training in aspects of industrial relations which is relevant to the carrying out of their duties and is approved by the TUC and/or their own union. Unions make their own agreements with employers but the TUC has suggested the following model agreement:

\section{"PAID RELEASE FOR TRAINING OF UNION REPRESENTATIVES}

1 In order to carry out their duties effectively union representatives shall receive appropriate training as approved by the TUC and/or their unions.

2 Union representatives shall be entitled to undertake such training in working hours without loss of any earnings (including bonus, overtime and all enhancements) which they would normally have earned had they been at work for the days at which they attend the course.

3 Where a union representative works on a shift or rota system, payment will be granted for one full shift per day of the course (including shift premium).

4 The employer will reimburse expenses and the cost of lunch and refreshments for attendance at day release courses.

5 This agreement will apply to the following types of training:-

(a) Induction Courses

Day/Block release courses involving a minimum of fifteen study hours.

-. I have a copy of the printed material used in this course. 
Release facilities will normally be made available within three months of the representative taking office, and as soon as possible for representatives who are already in office. Courses provided by unions will be suitable to meet this need.

(b) Basic Introductory Courses

TUC or appropriate union courses normally of 10-12 days. Release will be made available within twelve months of appointment for newly appointed representatives, and as soon as possible for representatives who are already in office.

(c) Further Training Courses

TUC or union courses normally of 10-12 days. These are intended for:-

(i) Representatives with special responsibilities (e.g. senior representatives, safety representatives, pension fund representatives)

(ii) Updating courses for all representatives, dealing with new developments. Each representative will normally attend three such courses in any three-year period.

(d) Advanced Courses

For key representatives such as convenors and union representatives serving on company boards. These will be longer courses, normally provided on a residential basis.

6 For the purpose of meeting these training needs TUC and union courses shall be deemed appropriate. The unions will notify management of any other courses which meet with their approval.

7 The union agrees to:

(a) Provide management with appropriate syllabuses of training courses where requested.

(b) Normally give a few weeks' notice of nominations for appropriate training.

(c) Take due account of the operational requirements of the employer.

8 The union and management shall endeavour to reach agreement on any problems arising from the operation of this agreement, and shall refer any differences to the normal procedure for dealing with disputes and grievances.

9 Notwithstanding any time limits in the normal procedure, the management appreciate that a decision will be required as quickly as possible, and in any event a reasonable time before the commencement of the course."

In addition the Health and Safety at Work, etc Act 1974 requires employers to grant union safety representatives paid time off for safety training by the union or the TUC. ** Not surprisingly these provisions have greatly increased the number of union officials undergoing training.

\section{The TUC - BBC - WEA trade union education scheme}

In 1975 the TUC joined with the BBC and the WEA, assisted by the Extramural Studies Department of Sheffield University, in a fascinating scheme which operates on the frontier between trade union training and broader trade union education. It is a three-year project which includes television programmes, postal courses, face-to-face tuition at day schools and study groups (very much on the model of the Open University). The titles of the three sections of

The text of this agreement is taken from a useful TUC guide entitled Paid Release for Union Training of which I have a copy I have a copy of the printed materials used in the TUC training programme for health and safety representatives. 
the course are The Bargaining System, Trade Unions and the Economy and Democracy at Work. * The television programmes feature discussions between unionists, interviews with unionists from other countries facing the same issues, role plays of bargaining situations, and, most important, the whole presentation is by unionists. The expertise of the educationists and the television specialists has been confined strictly to the design and organisation of the programmes - and there are none of the usual television front-men to intervene between the subject matter and the audience. Obviously too, large numbers of people will have watched these programmes and come to a better understanding of the trade union movement without actually being enrolled for the course.

\section{Trade union studies at universities, polytechnics, workers' colleges}

Equally on the frontier between training for specific union jobs and broader trade union education are the full-time courses which can be taken at the various workers' and trade union colleges. Best known of these is Ruskin College, Oxford, which provides one or two-year residential courses for adult workers. Coleg Harlech in North Wales and Hillcroft college near London offer the same kinds of courses. In addition, the London School of Economics and Political Science (LSE), which is part of the University of London, in collaboration with the TUC, holds a one-year full-time course in trade union studies. A similar one-year course is now offered by a technical institute, Gwent College of Higher Education in Newport, South Wales. In addition the new Northern College ${ }^{* *}$ near Barnsley offers a range of short courses including a five-week full-time course for shop stewards who have taken the two basic ten-week TUC day-release courses. They attend on paid leave granted by their employers (generally the National Coal Board since this is a mining area).

What impressed me most about the long courses in trade union studies was the way in which students were able to gain skills and information strictly relevant to their activities as trade unionists at the same time as furthering their general education. Scholarships to these institutions are available from the TUC and other sources.

One trade union, NALGO, has endowed a fellowship at Sussex University for research in trade union studies, which is held by someone taking leave from active work in the trade union movement. The University of Warwick has a School of Industrial and Business Studies and an Industrial Relations Research Unit which, unlike most such university departments, aim to offer their training facilities and consultancy services at least as much to trade unions as to management. Of particular interest too is the trade union information service unit attached to Southampton University specifically to act as a collection centre for information useful to trade unions.

\section{WEA, TUC and other adult education schemes}

Less individually substantial than the full-time courses (but still very important in their total impact) are the great variety of adult education classes, seminars, discussion groups etc on trade union matters organised by the WEA in collaboration with the trade unions. Many of these are conventional evening classes, but recently the WEA has introduced lunch-time sessions at the workplace which have been very popular and successful.

- I have copies of the books produced to accompany each course

- I have a copy of the prospectus of Narthern College. 
The TUC and some of the individual large unions also run correspondence courses, some of which relate to trade union matters, while others are for the general education of members.

\section{Three outstanding worker education schemes}

I want now to mention some schemes from the area of worker education in its broadest sense. Since this is a vast area I shall refer only to schemes in which the trade unions play a definite part and which are particularly innovative.

It is well known that when working people, whose formal education has not gone far, try to gain more educational experience as adults, they are very likely to be hampered by: lack of money, lack of time, lack of information and lack of assurance in approaching educational institutions. The projects I shall discuss now all aim to deal with at least one of these obstacles.

The Division of Continuing Education at the University of Sheffield identified a particular group of working-class people in South Yorkshire whose formal education was generally very limited - the coal miners - and developed, in conjunction with the National Union of Mineworkers, an educational programme which was open to them, and them only. It started with the miners talking about their own origins and experiences (in some respects very deprived, in other respects very rich) and then deciding as a group on their goals for the course, what they wanted to learn about, what skills they wanted to acquire. This programme has been in existence for over 20 years now and some of its fruits can be seen in a small book of memoirs produced by some of the miners South Yorkshire and the Mining People. The fact that the starting point for the programme is a given social group, rather than a predefined subject to be studied, has undoubtedly brought many people to educational experiences they would never have thought themselves capable of.

A scheme which aims to deal with the same problems but from a rather different point of view has established educational information centres in several large cities. They are particularly intended to serve people who think educational opportunities are unavailable or irrelevant to them. The centre I visited was the Educational Resources and Information Centre (ERIC) in Cardiff, which gets its financial sponsorship from the Open University and the Job Creation Scheme. It stores information on all post-school courses and educational opportunities and offers both information and counselling assistance to people wanting to further their education in any direction at all. The centre has made itself available to people who would normally feel cut off from any ideas of further education by, for instance, taking a caravan around working-class suburbs at which people can simply call in for assistance. Information slips are included in workers' pay packets telling them of the centre and the facilities it offers.

Probably the most radical and wide-ranging of all the worker education schemes that I encountered was the so-called "150 Hours" project in Italy. Quite simply, in 1973 the Italian Metalworkers' Union built into its national agreement with employers a clause giving all workers the automatic right to 150 hours paid leave per year (i.e. approximately 3 hours per week) for education. This scheme has subsequently been extended to cover many other unions and, in some cases, to give 250 hours per year educational leave. The Italian Ministry of Education shifted from initial non-cooperation with the scheme to an attempt to take it over entirely. In fact now the scheme uses school buildings, but the organisation of courses is by an independent centre(CEDOS) run by the trade unions and a group of committed educators. Broadly the par- 
ticipants begin by narrating their own work and life histories; they then undertake research projects intended to identify the particular economic, social, political and other forces which have shaped their lives; and the third phase has them putting together their various findings and trying to build up both an overall image of the structure of the whole society around them and a set of techniques for analysing it.

\section{Suggestions for developing trade union education in New Zealand}

New Zealand isn't South Wales, it isn't Italy and it doesn't have any unions with 2 million members! The whole basis and scale of trade union education in this country is bound to be quite different from that of the two countries I visited. Even so, I'm convinced that some elements can be borrowed from the schemes I looked at and adapted to our very different conditions. I want here to sketch in just a few of the directions in which I believe trade union education could (and should) develop in New Zealand.

Education has to be given a higher priority by people in the trade union movement. It's vital that unionists become fully aware of the sheer breadth of the spectrum of possibilities for trade union education and aim to develop projects across the whole of that spectrum. At the same time, the educational resources available both inside and outside the union movement must be used as effectively and economically as possible.

Starting from the training end of the spectrum: there is a strong argument for developing materials centrally for a basic 10 or 12-day job delegates' training course, including written and audiovisual material, which could be used by trainers throughout the country. Guidelines could be set down for the minimum length and scope of training courses for delegates and it would then become much easier to press for delegates to be automatically granted fully paid leave to attend such extended courses. At the same time, many more trainers (not necessarily full-time) need to be trained to lead such basic courses. The idea would not be to put a strait-jacket on the courses presently offered but rather to spread the knowledge and skills of the small number of existing trainers as widely as possible. A basic course of this kind could naturally be modified and extended by individual trainers to cover the particular needs of delegates in different kinds of workplace. The trade union movement should be bringing strong, and public, pressure on the big educational institutions for greater access to their resources than the unions currently enjoy. It should be possible immediately for trades councils and single unions to hold their training courses on the premises of, for instance, continuing education departments of universities-as already happens in some centres-using their rooms, audio-visual equipment, libraries, administrative resources etc. The teaching input from university staff might well be slight, or nil, at first. Unless they are already actually experienced in trade union education, academics can generally only make useful contributions in very specific areas such as: the psychology of negotiation, industrial law, economic issues, trade union history etc. What is needed is for the universities to respond in a helpful way to specific requests from the trade union movement, without in any way taking over or attempting to control trade union training, the initiative for which must always remain within the trade union movement itself. As the association between unions and the universities grows, so university staff may acquire a greater body of useful expertise which they can put back into trade union training.

Approaches should likewise be made to the radio and television authorities with a view to undertaking joint educational projects with them. Such projects 
could include the production of television programmes as part of a delegatetraining scheme. More probably, there could be a series of programmes directed at, and involving, trade unionists on issues of specific relevance to them-just as there are specialised programmes made for, and by, farmers, gardeners, motorists, and so on. Through such programmes trade unionists could debate the many issues that concern them in just the same way as the farmers discuss facial eczema, the gardeners talk about sowing carrots, and the motorists debate fuel-injection in their programmes. The fact that some non-unionists would see the programmes too should do the trade union movement nothing but good. The general public would, for once, be seeing trade unionists on their own terms, rather than in the context of an (often) inconvenient industrial dispute.

It is not realistic, at the moment, to think in terms of setting up in New Zealand separate trade union and workers' colleges as exist in Australia, Britain and some other countries. But the trade union movement should press for the inclusion of full labour studies and trade union studies courses in the technical institutes and universities. Such courses would not be under direct trade union control but the trade union movement could be influential in the setting up and running of such courses in just the same way as managerial and professional groups have an influence on courses taught in their fields. And what possible justification can there be for the existence of, say, personnel management courses at these institutions without corresponding courses in trade union studies? Similarly it would make good sense for trade unionists to seek election to the governing bodies of universities with a view to expressing a trade union viewpoint in that way too.

At the moment the trade union movement in New Zealand expresses its commitment to worker education mainly in terms of its, often rather vague, support for the WEA. This isn't enough. As the one movement capable of expressing the needs and aspirations of working people, the trade unions must commit themselves to a range of specific innovative projects of worker education. From the many possible projects I would suggest the following.

Trade unions could act as sponsors for the setting up of courses, seminars, discussion groups etc in the workplace. Trade unions could collaborate with the continuing education centres of universities in the provision of truly workeroriented education programmes-and there is little doubt that the universities will need some bullying to do this. (It's a strange effect of the widespread myth that there is no class-system in New Zealand, that there are probably fewer educational provisions for working-people in this country than there are in countries where the class-structure is more obvious.) Trades councils could consider making a part of their premises available as vigorous worker education centres, with libraries, study facilities, educational counsellors, attached. And trade unionists might well take a leading role in setting up mobile education information centres to visit the working-class suburbs of the big cities and outlying settlements associated with timber-mills and so on. At the same time, trade unions should be bringing the strongest pressure to bear on the government and political parties for legislation requiring all workers to be permitted paid leave to further their education - in a period of high unemployment this is a quite obvious way of bringing about a kind of work-sharing.

You will appreciate that what I am suggesting here is no more than a handful of the possible educational projects which the trade unions could become involved in. Other people will see quite different possibilities. All that matters that they do something to bring them into existence. 